\title{
INFLUENCE OF WASTEWATER TREATMENT AND THE METHOD OF SLUDGE DISPOSAL ON THE GASIFICATION PROCESS
}

\author{
WPEYW OCZYSZCZANIA ŚCIEKÓW I SPOSOBU ZAGOSPODAROWANIA \\ OSADÓW ŚCIEKOWYCH NA PROCES ZGAZOWANIA
}

\begin{abstract}
Municipal wastewater treatment results in the production of large quantities of sewage sludge, which requires proper environmentally accepted management before final disposal. Sewage sludge is a by-product of current wastewater treatment technologies. Sewage sludge disposal depends on the sludge treatment methods used in the wastewater treatment plant (anaerobic or aerobic digestion, drying, etc.). Taking into consideration presented given this information, a study concerning the effects of wastewater treatment processes and sewage sludge drying method on the sewage sludge gasification gas parameters was performed. Gasification is a prospective alternative method of sludge thermal treatment. For the purpose of experimental investigations, a laboratory fixed bed gasifier installation was designed and built. Two types of sewage sludge feedstock, SS1 and SS2, were analyzed. Sewage sludge SS1 came from a wastewater treatment plant operating in the mechanical and biological system while sewage sludge SS2 was collected in a mechanical, biological and chemical wastewater treatment plant with simultaneous phosphorus precipitation. The sludge produced at the plants was subject to fermentation and then, after being dehydrated, dried in a cylindrical drier on shelves heated up to $260^{\circ} \mathrm{C}$ (sewage sludge SS1) and using hot air at a temperature of $150^{\circ} \mathrm{C}$ in a belt drier (sewage SS2). The analysis shows that the sewage sludge properties strongly depend on the wastewater sources and the wastewater treatment processes. The gasification results, presented as a function of the amount of gasification agent, show that the greater oxygen content of SS1 caused a reduction in the reaction temperature. Paradoxically, this effect caused an increase in the quantity of combustible components in the gas. As expected, increasing the air flow rate caused a decrease in the heating value of the gas produced. A higher amount of oxidizer increases the amounts of noncombustible species and the volumetric fraction of nitrogen, thus reducing the heating value of the obtained gas. The higher hydrogen content in SS1 affects the gasification gas composition. As a result, combustible components are the majority of the syngas.
\end{abstract}

Keywords: wastewater treatment, sludge treatment, sewage sludge properties, gasification, fuel properties, gasification gas parameters

\footnotetext{
${ }^{1}$ Institute of Thermal Technology, Silesian University of Technology, ul. Konarskiego 22, 44-100 Gliwice, Poland, phone +48 3223729 83, fax +48 3223728 72, email: sebastian.werle@ polsl.pl

${ }^{2}$ Institute of Water and Wastewater Engineering, Silesian University of Technology, ul. Konarskiego 18, 44-100 Gliwice, Poland, phone +48 3223716 98, fax +48 3223710 47, email: mariusz.dudziak@ polsl.pl

*Corresponding author: sebastian.werle@polsl.pl
} 


\section{Introduction}

In Europe, there have been significant changes to the human population connected to wastewater treatment over the last twenty years. Changes have also occurred in the treatment techniques used [1]. In northern European countries, where the majority of the population is connected to wastewater treatment plants, the waste treatment process typically involves three stages: (i) mechanical wastewater treatment; (ii) biological wastewater treatment, which is usually performed in a biological reactor consisting of an anaerobic dephosphatation zone, an anaerobic denitrification zone and an aerobic nitrification zone; and (iii) biological deposit or filtration for the final stage [1-4]. This system effectively removes nitrogen, phosphorus and organic matter from wastewater. Sometimes, to achieve a lower concentration of phosphorus in wastewater, a simultaneous dephosphatation precipitation based on iron or aluminum salts (eg) is used. These salts are added to the aerobic nitrification zone [4]. In southern and eastern European countries, approximately half of the population is connected to a wastewater treatment plant, which is usually based on two stages: (i) mechanical and (ii) biological wastewater treatment [2]. However, the overall increment of the inhabitants connected to wastewater treatment leads to an increase in the amount of sludge produced [1]. The quantity of sludge production in Europe $[5,6]$ varies widely in different countries (16-94 g/(person-day)). As the population increases, there is an increase in the production of sewage sludge. Moreover, final sewage sludge disposal depends on the sludge treatment methods used in the wastewater treatment plant (anaerobic or aerobic digestion, drying, thermal utilization, etc.). In European countries, anaerobic stabilization is more popular (in 24 countries) than aerobic stabilization (in 20 countries) [5]. Unfortunately, the most popular method of final sewage sludge management is storage. In countries that are technologically less developed, direct agricultural application or land filling are the typical pathways to safely dispose of stabilized sludge from wastewater treatment plants. In countries where policy makers have practically forbidden such solutions ( $\mathrm{eg}$, the European Union), only thermal disposal methods are available. The thermo-chemical conversion of sewage sludge consists of four main processes: combustion, co-combustion, pyrolysis and gasification [7]. One of the promising thermo-chemical conversion technologies that can be used to convert sewage sludge to useful energy forms suited for small to medium size throughput is gasification. Chemical and physical phenomena that occur during the gasification of sewage sludge are essentially similar to typical carbonaceous material thermal decomposition. Through gasification, sewage sludge can be transformed into a secondary energy carrier, which creates various possibilities for further use. The product gas can be utilized for power production in combined heat and power (CHP) plants, the production of biofuels through Fischer Tropsch synthesis, synthetic natural gas (SNG) production or the production of basic chemicals, such as dimethyl ether [8]. The added value of sewage sludge gasification is connected with a limited amount of dioxin, $\mathrm{SO}_{2}$ and $\mathrm{NO}_{\mathrm{x}}$ formation during the process. Sulfur is mainly transformed to $\mathrm{H}_{2} \mathrm{~S}$ [9] and $\mathrm{N}_{2}$ into $\mathrm{NH}_{3}$ [10]. Phosphorus is partitioned into solid residues [11] in gasification. For all of these reasons, gasification requires smaller and less expensive gas-cleaning facilities [12]. 


\section{Gasification of sewage sludge - main reactions}

Gasification is the conversion of solid (or liquid) feedstock into useful and convenient gaseous fuel (or chemical feedstock) that can be burned to release energy or used for production of value-added chemicals [13]. A typical sewage sludge gasification process may include the following steps: (i) drying, (ii) thermal decomposition or pyrolysis, (iii) partial combustion of some gases, vapors and char, (iv) gasification of decomposition products. Gasification requires a gasifying medium like steam, air or oxygen to rearrange the molecular structure of the feedstock in order to convert the solid feedstock into gases or liquids. The main reactions involved during the gasification of organic substances are summarized below [14]:

Boudouard: $\mathrm{C}+\mathrm{CO}_{2} \rightarrow 2 \mathrm{CO}$

Water gas (primary): $\mathrm{CO}+\mathrm{H}_{2} \mathrm{O} \rightarrow \mathrm{CO}+\mathrm{H}_{2}$

Water gas (secondary): $\mathrm{C}+2 \mathrm{H}_{2} \mathrm{O} \leftrightarrow \mathrm{CO}_{2}+2 \mathrm{H}_{2}$

Methanation: $\mathrm{C}+2 \mathrm{H}_{2} \leftrightarrow \mathrm{CH}_{4}$

Water gas shift: $\mathrm{CO}+\mathrm{H}_{2} \mathrm{O} \leftrightarrow \mathrm{CO}_{2}+\mathrm{H}_{2}$

Steam reforming: $\mathrm{CH}_{4}+\mathrm{H}_{2} \mathrm{O} \leftrightarrow \mathrm{CO}+3 \mathrm{H}_{2}$

Dry reforming: $\mathrm{CH}_{4}+\mathrm{CO}_{2} \leftrightarrow 2 \mathrm{CO}+2 \mathrm{H}_{2}$

Gasification has attracted attention as one of the most efficient methods for utilizing biomass as $\mathrm{CO}_{2}$ emission has become an important global issue.

Given this information, a study was performed on the effects of the wastewater treatment process and sewage sludge drying method on the sewage sludge-derived fuel properties and sludge gasification gas parameters.

\section{Methodology}

\section{Dried sewage sludge properties}

Two types of sewage sludge feedstock were analyzed. Sewage sludge no. 1 (SS1) was taken from a Polish wastewater treatment plant operating a mechanical-biological system, and sewage sludge no. 2 (SS2) was taken from a mechanical-biological-chemical wastewater treatment plant with phosphorus precipitation. The mechanical-biological component of both analyzed wastewater treatment plants was similar. They consisted of commonly used processes: a pump station, a bar screen, grit chambers, and primary sedimentation tanks. In both analyzed cases, the biological component of the wastewater treatment plant used a modified Bradenpho configuration with low load activated sludge. There is only one difference between the wastewater treatment plants. In the mechanical-biological-chemical wastewater treatment plant, coagulant PIX-113 containing iron(III) sulfate (Kemipol, Poland) was added directly to the biological reactors to support chemical precipitation of phosphorus. It should be noted that chemical precipitation of phosphorus also has a strong impact on the decrease of the concentration of organic matter from wastewater. It acts on the calorific value of the sludge and will be considered in the later parts of this work. Wastewater effluent from both analyzed wastewater treatment plants fulfilled the Polish regulations, especially the Minister of Environment Regulation concerning the conditions for sewage sludge being added to water and soil [15]. Additionally, in both analyzed cases, the sewage sludge was stabilized by anaerobic digestion and dehydration. The anaerobic digestion of sewage sludge, a well-developed and 
established technology, produces "green" energy in the form of biogas, which is suitable for CHP (combined heat and power) or CCHP (combined cold, heat and power) systems. The anaerobic digestion process has the incredible limitation that it is unable to sufficiently recover energy from sludge. As a consequence, the digested sludge still has the potential for energy use. Thus, after anaerobic digestion, the sewage sludge was dried. In case 1 (SS1), the sewage sludge was dried in a cylindrical dryer with a heated shelf. The temperature of the hot air was $260^{\circ} \mathrm{C}$ (high temperature). In case 2 (SS2), an air belt dryer was used. The temperature of the hot air in this case was $150^{\circ} \mathrm{C}$ (low temperature). As a consequence, in case 1, the form of the dried sludge was similar to granulate (Fig. 1a) and to "noodles", in case 2 (Fig. 1b). Anaerobic digestion followed by drying and gasification can lead to a sustainable process applicable for high sewage sludge to bioenergy conversion, and the simultaneously integrated process can potentially reduce the amount of solid waste to be deposited. Such different sludge drying temperatures can also affect the calorific value of sewage sludge.

a)

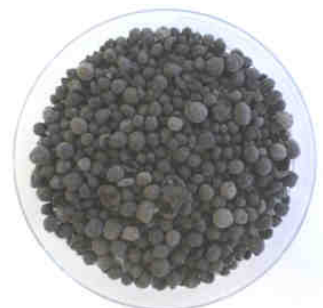

b)

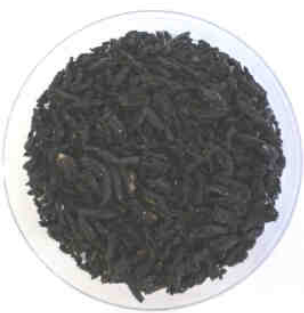

Fig. 1. Pictures of the analyzed sewage sludge: a) SS1 and b) SS2

The main element in the sewage sludge was determined using automatic infrared (IR) analyzers. The heavy metal content in the sludge was determined by absorption spectroscopy. The moisture content of the sewage sludge was obtained following standard PN-EN 14774-3:2010 [16]. The sludge volatile content was determined according to standard PN-EN 15402:2011 [17]. The sludge ash content was obtained using PN-EN 15403:2011 [18]. The High Heating Values were experimentally measured with a bomb-calorimeter, and the Low Heating Values were calculated on from the hydrogen content on a dry basis. Ash behavior and deposition tendencies were predicted through the use of empirical indices for sludge ashes. Slagging and fouling indexes: Base to Acid index (B/A), Sintering Index (SI), Alkali Index (AI) and Bad Agglomeration Index (BAI) were calculated from ash chemical composition. Base to Acid index [19] was calculated according following equation:

$$
\mathrm{B} / \mathrm{A}=\frac{\mathrm{CaO}+\mathrm{MgO}+\mathrm{K}_{2} \mathrm{O}+\mathrm{Na}_{2} \mathrm{O}+\mathrm{Fe}_{2} \mathrm{O}_{3}}{\mathrm{SiO}_{2}+\mathrm{TiO}_{2}+\mathrm{Al}_{2} \mathrm{O}_{3}}
$$

Being that: if $\mathrm{B} / \mathrm{A}<0.75$, slagging trend can be expected.

The following sintering index [17] was calculated according to following equation:

$$
\mathrm{SI}=\frac{\mathrm{CaO}+\mathrm{MgO}}{\mathrm{Na}_{2} \mathrm{O}+\mathrm{K}_{2} \mathrm{O}}
$$


Being that: no slagging should be expected at values of $\mathrm{SI}>2$, whereas the slagging risk should be high at $\mathrm{SI}<2$.

Alkali index [22] was calculated according to the following equation:

$$
\mathrm{AI}=\frac{\mathrm{CaO}+\mathrm{MgO}+\mathrm{K}_{2} \mathrm{O}+\mathrm{Na}_{2} \mathrm{O}+\mathrm{Fe}_{2} \mathrm{O}_{3}}{\mathrm{SiO}_{2}+\mathrm{Al}_{2} \mathrm{O}_{3}}
$$

When the AI increases, slagging tendency increases.

For evaluating the risk of bed agglomeration in fluidized bed combustion, the following bed agglomeration index (BAI) [19] was calculated according to the following equation:

$$
\mathrm{BAI}=\frac{\mathrm{Fe}_{2} \mathrm{O}_{3}}{\mathrm{~K}_{2} \mathrm{O}+\mathrm{Na}_{2} \mathrm{O}}
$$

Being that: bed agglomeration occurs when BAI $<0.1$, following [20].

These indices, despite their shortcomings due to the complex conditions, which arise in boilers and their associated heat transfer equipment, are widely used and probably remain the most secure basis for decision making, if used in conjunction with pilot plant testing.

The ash-fusion temperatures, indicator of slagging tendency in gasification/ combustion systems, were measured in laboratory in reducing atmosphere in accordance with the microscope-photograph method CEN/TS 15404:2006 [21].

\section{Experimental setup and procedure}

The sewage sludge gasification tests were conducted using a fixed bed gasification facility, which has been described earlier [22]. A photograph of the installation is shown in Figure 2.

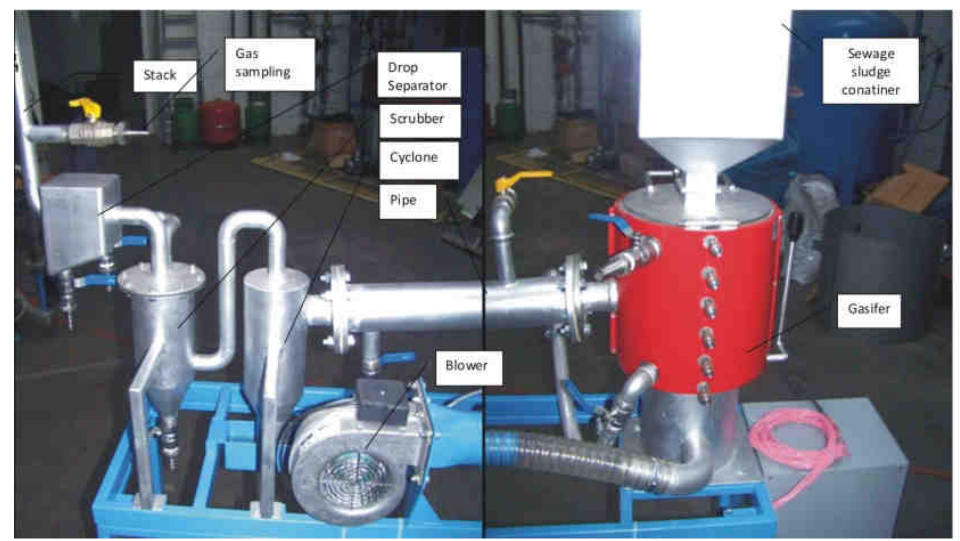

Fig. 2. Experimental stand for sewage sludge gasification tests

Granulated sewage sludge from the sewage sludge container was fed into the reactor. Table 1 shows the operating conditions for all the experiments. The air excess ratio $\lambda$ was defined, as typically used in the European Union, as the inverse of the equivalence ratio $\Phi$, $i e$, the ratio of the actual air to fuel ratio to the stoichiometric air to fuel ratio. A fraction of the gases produced during gasification was first passed through a condensing system, which 
removed the condensables, followed by a set of filters for particulate removal to allow clean gas for off-line chromatographic analysis. Gas chromatograph analysis was used to determine the gas composition in terms of the volume percentages of $\mathrm{N}_{2}, \mathrm{O}_{2}, \mathrm{CO}, \mathrm{H}_{2}, \mathrm{CO}_{2}$ and $\mathrm{CH}_{4}$. The gas compositions were determined by a gas chromatograph (Agilent $6890 \mathrm{~N}$ series) equipped with thermal conductivity detector (TCD) and capillary columns ( $30 \mathrm{~m} \times 0.53 \mathrm{~mm} \times 3 \mu \mathrm{m}$ Carbonplot with $30 \mathrm{~m} \times 0.53 \mathrm{~mm} \times 25 \mu \mathrm{m}$ Molesieve). The oven temperature was initially maintained at $50^{\circ} \mathrm{C}$; after $9 \mathrm{~min}$, the temperature was increased at a rate of $15^{\circ} \mathrm{C} / \mathrm{min}$ until it reached $200^{\circ} \mathrm{C}$, where it was held for $30 \mathrm{~min}$. The detector and injector temperatures were $250^{\circ} \mathrm{C}$ and $200^{\circ} \mathrm{C}$, respectively. The flow rate of the carrier gas, helium, was $8.9 \mathrm{~cm}^{3} / \mathrm{min}$. A GC calibration was performed using a certified standard gas.

Table 1

Operating conditions used for sewage sludge gasification process

\begin{tabular}{|c|c|c|}
\hline Gasification agent & Air excess ratio $\lambda$ & Gasification agent temperature [K] \\
\hline \multirow{2}{*}{ Atmospheric air } & $0.12 ; 0.14 ; 0.16 ;$ & $\mathrm{T}_{1}=298 ; \mathrm{T}_{2}=323 ;$ \\
& $0.18 ; 0.23 ; 0.27 ;$ & $\mathrm{T}_{3}=373 ; \mathrm{T}_{4}=423 ;$ \\
& $\mathrm{T}_{5}=473 ; \mathrm{T}_{5}=473 ;$ \\
\hline
\end{tabular}

\section{Results and discussion}

\section{Physical and chemical properties of sewage sludge}

Table 2 summarizes the main physical and chemical properties of the sewage sludge used. The ultimate analysis results show that the sewage sludge from the mechanicalbiological-chemical wastewater treatment plant with phosphorus precipitation (SS2) compared to the sewage sludge from the mechanical-biological wastewater treatment plant (SS1) is characterized by lower amounts of $\mathrm{C}, \mathrm{H}, \mathrm{N}, \mathrm{O}, \mathrm{F}$ and $\mathrm{Cl}$. This difference is a result of the chemical precipitation of phosphorus that was used in the mechanical-biologicalchemical wastewater treatment (and SS2). In this case, the effect of the drying temperature was negligible, especially because in the case of SS2, the drying temperature was lower than that of SS1. This feature indicates the lower utility of sludge SS2 in thermal treatment. Additionally, this feature proves that the in-depth waste treatment configuration has a direct impact on the calorific value (expressed by the lower heating value (LHV) or the higher heating value (HHV)) of the derived fuel from sewage sludge. The LHV (and HHV) of SS2 is lower than that of SS1. Nevertheless, in both analyzed cases, the HHV is lower than $6 \mathrm{MJ} / \mathrm{kg}$, which is the limit value for possible sewage sludge storage in a waste landfill (based on the Polish criteria for the storage of sewage sludge in a non-hazardous waste landfill [22]). It should also be emphasized that SS2 is prepared using a lower drying temperature than SS1. This feature also significantly affected the calorific value of the fuel from sludge.

Although the final effect on wastewater treatment in the analyzed cases was approximately at the same level (unpublished results), strong differences were observed in the heavy metal concentrations between SS1 and SS2. In this context, the mechanicalbiological-chemical wastewater treatment plant is preferable.

By analyzing the presented results, it can also be observed that the average sizes of the analyzed sludge are different. The average area of a single SS2 element is 10 times larger than that of SS1 due to the addition of precipitating compounds in the wastewater treatment 
stage. An increase in particle size resulted in a reduction of the effective surface available for the reaction, which inhibited the transport of mass and heat to the thermochemical process.

Based on the determined ash behavior indexes it was concluded that both of the sludge analyzed are characterized much less fouling tendency and - unfortunately - much higher slagging and agglomeration tendency.

Sewage sludge properties used in the gasification tests

\begin{tabular}{|c|c|c|}
\hline & \multicolumn{2}{|c|}{ Symbol of sewage sludge } \\
\hline & SS1 & SS2 \\
\hline $\begin{array}{c}\text { Wastewater treatment plant } \\
\text { configuration }\end{array}$ & $\begin{array}{c}\text { mechanical- } \\
\text { biological }\end{array}$ & $\begin{array}{c}\text { mechanical-biological- } \\
\text { chemical }\end{array}$ \\
\hline Sludge form & granulate & noodles \\
\hline Drying method & cylindrical dryer & belt dryer \\
\hline Drying temperature & $260^{\circ} \mathrm{C}$ & $150^{\circ} \mathrm{C}$ \\
\hline \multicolumn{3}{|c|}{ Geometry of sludge } \\
\hline The average area $\left[\mathrm{mm}^{2}\right]$ & 20.00 & 200.00 \\
\hline \multicolumn{3}{|c|}{ Proximate analysis [\%] (as received) } \\
\hline Moisture & 5.30 & 5.30 \\
\hline Volatile matter & 51.00 & 49.00 \\
\hline Ash & 36.50 & 44.20 \\
\hline \multicolumn{3}{|c|}{ Ultimate analysis [\%] (dry basis) } \\
\hline $\mathrm{C}$ & 31.79 & 27.72 \\
\hline $\mathrm{H}$ & 4.36 & 3.81 \\
\hline $\mathrm{N}$ & 4.88 & 3.59 \\
\hline $\mathrm{O}$ (by difference) & 57.07 & 63.04 \\
\hline \multicolumn{3}{|c|}{ Heavy metal contents [mg/kg] (dry basis) } \\
\hline $\mathrm{Zn}$ & 920.90 & 991.20 \\
\hline $\mathrm{Cu}$ & 495.30 & 183.16 \\
\hline $\mathrm{Pb}$ & 119.30 & 59.97 \\
\hline $\mathrm{Ni}$ & 103.67 & 18.90 \\
\hline $\mathrm{Cr}$ & 180.53 & 584.53 \\
\hline $\mathrm{Cd}$ & 6.47 & 3.24 \\
\hline As & 4.19 & 3.94 \\
\hline $\mathrm{Hg}$ & 0.99 & 0.96 \\
\hline $\mathrm{Se}$ & 9.84 & 1.70 \\
\hline \multicolumn{3}{|c|}{ Calorific value $[\mathrm{MJ} / \mathrm{kg}]$ (on dry basis) } \\
\hline HHV & 14.05 & 11.71 \\
\hline LHV & 12.96 & 10.75 \\
\hline \multicolumn{3}{|c|}{ Ash indexes [\%] } \\
\hline Bace to acid index (B/A) & 1.06 & 1.19 \\
\hline Sintering index (SI) & 22.85 & 7.92 \\
\hline Alkali index $(\mathrm{AI})$ & 39.93 & 53.68 \\
\hline Bad agglomeration index (BAI) & 6.70 & 6.46 \\
\hline
\end{tabular}

\section{Sewage sludge gasification process}

Table 3 summarizes the sewage sludge gasification gas composition for an air excess ratio of $\lambda=0.18$. The air excess ratio was calculated according to the following equation given the gasification air and sludge ratio $m_{\text {air }} / m_{\text {fuel }}$, the minimum amount of air $1 / n_{\text {airmin }}$ required for complete combustion and the molecular weight of air $1 / M_{\text {air }}$ : 


$$
\lambda=\frac{m_{\text {air }}}{m_{\text {fuel }} \cdot n_{\text {air } \min } \cdot M_{\text {air }}}
$$

The gas composition was determined from chromatographic analysis (Fig. 3a, b).

Table 3

Sewage sludge gasification gas compositions $(\lambda=0.18)$

\begin{tabular}{|c|c|c|}
\hline & \multicolumn{2}{|c|}{ Symbol of sewage sludge } \\
\cline { 2 - 3 } & SS1 & SS2 \\
\hline $\mathrm{CH}_{4}[$ vol. dry basis \%] & 0.85 & 0.77 \\
\hline $\mathrm{H}_{2}$ [vol. dry basis \%] & 5.50 & 4.50 \\
\hline $\mathrm{CO}^{2}$ vol. dry basis \%] & 21.70 & 20.00 \\
\hline $\mathrm{CO}_{2}[$ vol. dry basis \%] & 16.50 & 18.06 \\
\hline $\mathrm{N}_{2}[$ vol. dry basis \%] & 55.45 & 56.67 \\
\hline $\mathrm{LHV}\left[\mathrm{MJ} / \mathrm{m}^{3}\right.$ ] & 3.65 & 3.28 \\
\hline
\end{tabular}

a)

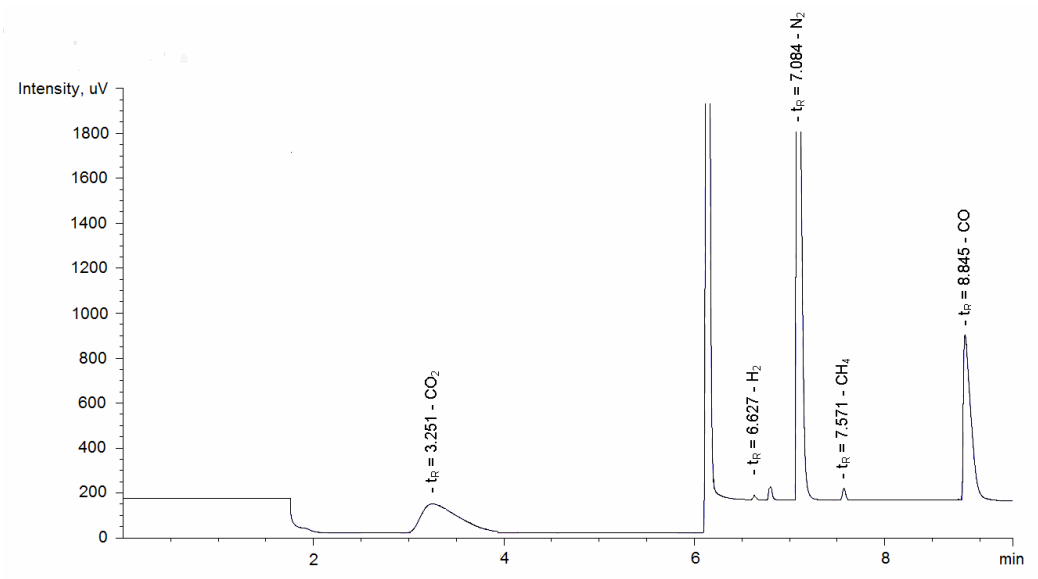

b)

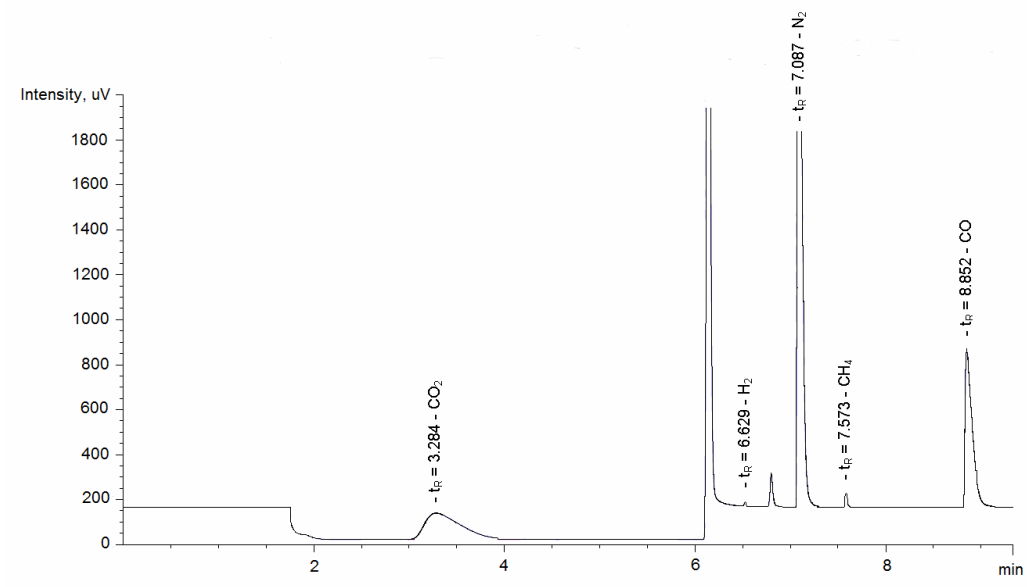

Fig. 3. Chromatograms from sewage sludge gasification: a) SS1 and b) SS2 $(\lambda=0.18)$ 
As shown in Table 3, the calorific value of the gas obtained from SS1 is higher than that from SS2 due to the composition of the sewage sludge. The higher values of the main components (especially $\mathrm{C}$ and $\mathrm{H}$ ) in the SS1 affect the LHV of the gasification gas. Additionally, when the particle size increased (SS2 particles are much larger than SS1 particles), the apparent density of the sludge (solid fuel per bed volume) decreased, and the process tended to combustion, as shown by the increasing concentration of carbon dioxide and nitrogen. This trend is also observed in Table 3.

The study also included the effect of the amount of supplied air gasification (expressed as the air excess ratio $\lambda$ ) on the composition of the gas from gasification. Figure 4 shows the evolution of the $\mathrm{H}_{2}, \mathrm{CO}, \mathrm{CO}_{2}$ and $\mathrm{CH}_{4}$ concentrations in the gasification gas with varying air excess ratios for both sludge.

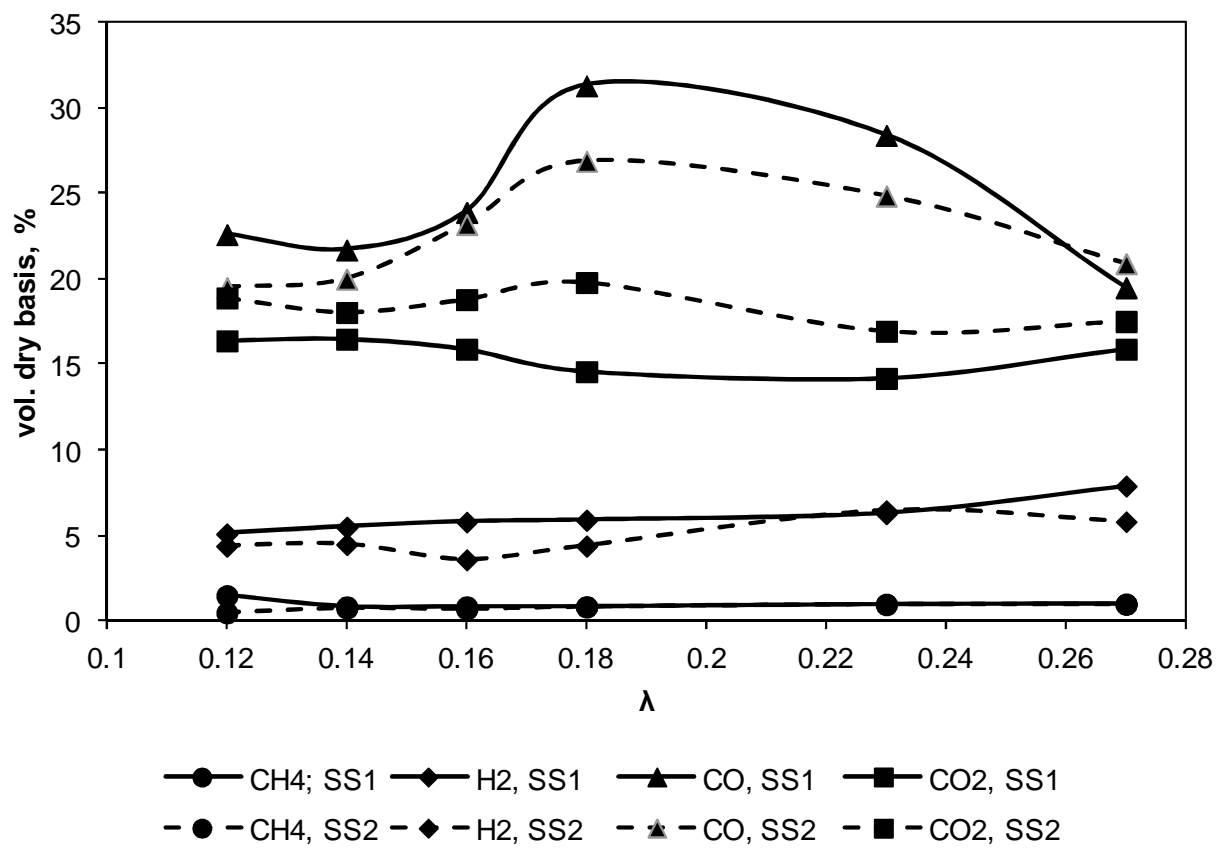

Fig. 4. Evolution of the $\mathrm{H}_{2}, \mathrm{CO}, \mathrm{CO}_{2}$ and $\mathrm{CH}_{4}$ concentrations in the gasification gas with varying air excess ratios for both sludge

Throughout the range of air excess ratios analyzed $(\lambda=0.12-0.27)$, the volumetric fraction of the main combustible components of the gasification gas $\left(\mathrm{CO}\right.$ and $\left.\mathrm{H}_{2}\right)$ are higher for SS1 (positive aspect) compared to SS2. Conversely, the volumetric fraction of carbon dioxide from the SS2 gasification process is higher in the range of air excess ratios analyzed (negative aspect). The amount of $\mathrm{CH}_{4}$ is almost constant for both feedstocks in the range of air excess ratios analyzed. As mentioned above, this effect primarily results from the composition (as an effect of the wastewater treatment configuration) and the particle size of the sewage sludge (an indirect effect of the drying method used). 
Figure 5 shows the evolution of the lower heating value of both sewage sludge feedstock gasification gases. Given the lower heating value, LHV, of the gasification gas, the optimum value of the air excess ratio is 0.18 , at which LHV has a maximum value regardless of the sewage sludge type.

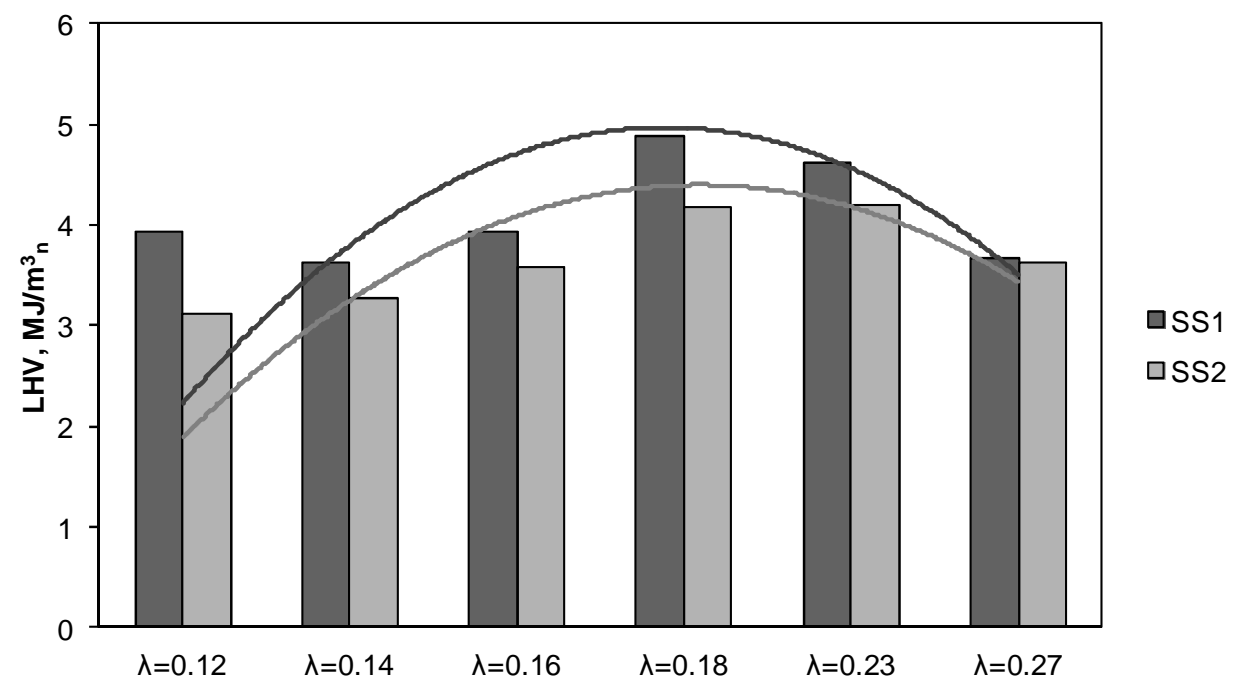

Fig. 5. Evolution of the LHV of the gasification gas with varying air excess ratios for both sludge

\section{Gasification temperature profile}

The temperature profiles in the reactor were measured by six N-type thermocouples installed at six points along the vertical axis of the reactor. The temperatures were measured at the following distances above the grate, $T_{1}: 10 \mathrm{~mm}, T_{2}: 60 \mathrm{~mm}, T_{3}: 110 \mathrm{~mm}, T_{4}: 160 \mathrm{~mm}$, $T_{5}: 210 \mathrm{~mm}$ and $T_{6}: 260 \mathrm{~mm}$. Figure 6 shows that the bed temperature increased gradually with increments in the air excess ratio, indicating that the bed temperature distribution was affected almost monotonically by the variation in the air excess ratio. The increase in the oxygen concentration with an increase in the air excess ratio shows that the exothermic reaction was favored in the gasifier.

The temperatures reported in this investigation all correspond to average temperatures. Figure 7 shows that air preheating produced an increase in the reactor temperature. The high temperature of the air facilitated the production of a gas with a higher calorific value than would have been obtained with a "cold" gasifier agent. The high temperature made it possible to obtain the same gasification temperature at lower air excess ratios, thereby decreasing the volume of producer gas obtained and clearly reducing the size and cost of the gasification installation and gas cleaning equipment required. It should be emphasized that high temperature air is a low-cost gasification agent that is typically a waste air stream that would be irretrievably lost if it were not used for gasification. Afterwards, more heat was released, resulting in an increasing bed temperature. 


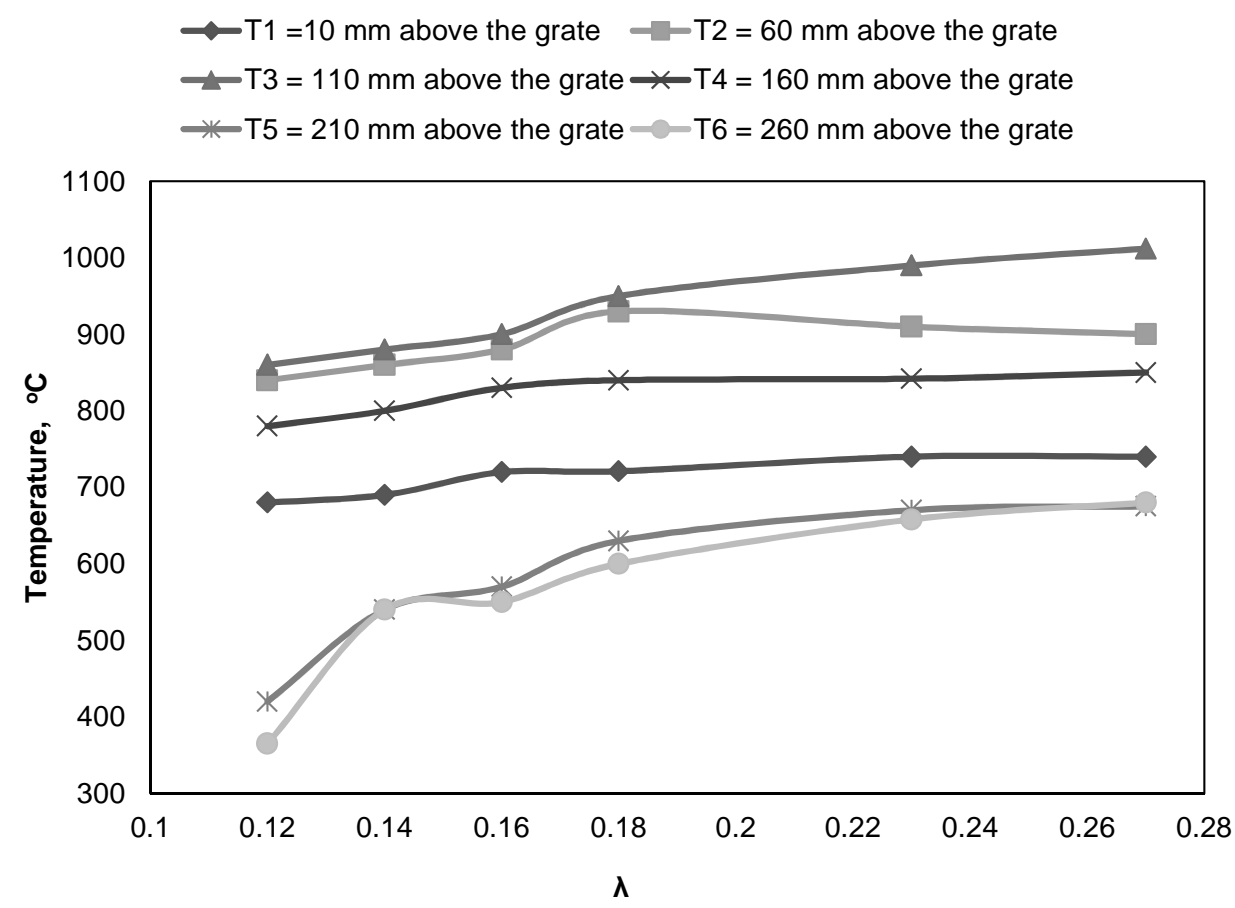

Fig. 6. Temperature profile in gasifier

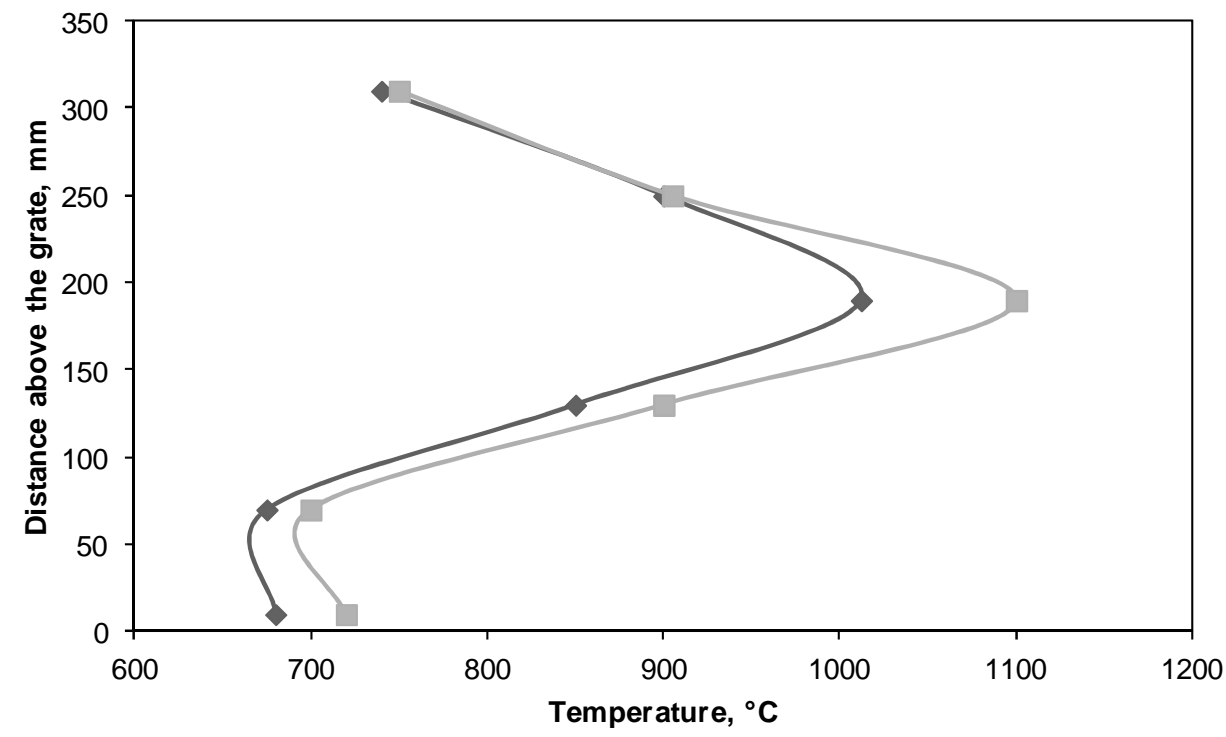

$\sim$ cold air $\quad-$ preheated up to $523 \mathrm{~K}$ air

Fig. 7. Steady temperature profile; $\lambda=0.28$ - effect on air preheating 
That Figure also shows that the temperature at $T_{3}$ was always the highest temperature in the reactor; thus, $T_{3}$ may have been located in the partial oxidation zone, which would have been the hottest area in the downdraft fixed bed gasifier. Correspondingly, the other monitoring sites may have been located as follows: $T_{6}$ and $T_{5}$ in the drying zone, $T_{4}$ in the pyrolysis zone, $T_{2}$ in the oxidation (combustion) zone and $T_{1}$ in the ash zone.

\section{Conclusions}

According to the results of the experimental work conducted on the effect of the wastewater treatment process and the sewage sludge drying method on the sewage sludge-derived fuel properties and the sludge gasification gas parameters, the following conclusions can be drawn:

1. Sewage sludge from the mechanical-biological-chemical wastewater treatment plant with phosphorus precipitation (SS2) is characterized by lower amounts of $\mathrm{C}, \mathrm{H}, \mathrm{N}, \mathrm{O}, \mathrm{F}$ and $\mathrm{Cl}$ compared to the sewage sludge from mechanical-biological wastewater treatment plant (SS1).

2. The in-depth waste treatment configuration has a direct impact on the calorific value (expressed by the lower heating value (LHV) or the higher heating value (HHV)) of the derived fuel from sewage sludge. The LHV (and HHV) of sewage sludge from the mechanical-biological-chemical wastewater treatment plant with phosphorus precipitation is lower than that from the mechanical-biological wastewater treatment plant.

3. The drying temperature of sewage sludge causes the calorific value of the refuse-derived fuel from sludge. The higher the drying temperature is, the lower the LHV.

4. An increase in the particle size resulted in a reduction of the effective surface available for reaction, which inhibited the transport of mass and heat to the thermochemical process.

5. Higher values of the main components (especially $\mathrm{C}$ and $\mathrm{H}$ ) in the sewage sludge from mechanical-biological wastewater treatment plant affected the increase of the LHV of the gasification gas.

6. When the particle size increased, the apparent density of the sludge (solid fuel per bed volume) decreased, and the process tended to combustion, which was observed as increasing concentrations of carbon dioxide and nitrogen.

7. Throughout the range of air excess ratios analyzed $(\lambda=0.12-0.27)$, the volumetric fractions of the main combustible components of gasification gas $\left(\mathrm{CO}\right.$ and $\left.\mathrm{H}_{2}\right)$ are higher in the case of sewage sludge 1 (positive aspect) than SS2.

8. Given the lower heating value, LHV, of the gasification gas, there is an optimum value of the air excess ratio equal to 0.18 , at which the LHV has a maximum value regardless of the sewage sludge type.

9. The operating conditions of sewage sludge gasification greatly influence the gasifier temperature profile and the syngas composition distribution.

\section{Acknowledgments}

The paper has been prepared within the frame of the National Science Centre project based on decision no DEC-2011/03/D/ST8/04035. 


\title{
References
}

[1] 6th Commission summary on the implementation of the Urban Waste Water Treatment Directive, European Commission Staff Working Paper, Brussels, 7.12.2011.

[2] Smolyody L, Patziger M. Water Sci Technol. 2012;66:1081-1087. DOI: 10.2166/wst.2012.289.

[3] Aggeli K, Kalavrouziotis IK, Bezergianni S. Fresen Environ Bull. 2009;18:1295-1301.

[4] Banu JR, Do KU, Yeom IT. World J Microb Biot. 2008;24:2981-2986. DOI: 10.1007/s11274-008-9841-0.

[5] Kelessidis A, Stasinakis AS. Waste Manag. 2012;32:1186-1195. DOI: 10.1016/j.wasman.2012.01.012.

[6] Cao Y, Pawłowski A. Renew Sust Energ Rev. 2012;16:1657-1665. DOI: 10.1016/j.rser.2011.12.014.

[9] Magdziarz A, Werle S. Waste Manag. 2014;1:174-179. DOI: 10.1016/j.wasman.2013.10.033.

[10] Chang J, Fu Y, Luo Z. Biomass Bioenergy. 2012;39:67-72. DOI: 10.1016/j.biombioe.2011.01.044.

[11] Marrero TW, McAuley BP, Sutterlin WR, Morris JS, Manahan SE. Waste Manag. 2004;24:193-198. DOI: 10.1016/S0956-053X(03)00127-2.

[12] Kobayashi N, Tanaka M, Piao G, Kobayashi J, Hatano S, Itaya Y, et al. Waste Manag. 2009;29:245-251. DOI: 10.1016/j.wasman.2008.04.014.

[13] Thanapal SS, Annamalai K, Sweeten JM, Gordillo G. Applied Energy. 2012;97:525-531. DOI: 10.1016/j.apenergy.2011.11.072.

[14] Buckley JC, Schwarz PM. Environ Monitor and Assess. 2003;84:111-27. DOI: 10.1023/A:1022847416139.

[15] Werle S. Environ Prot Eng. 2013;39:25-32. DOI: 10.5277/EPE130203.

[16] Taba LE, Irfan MF, Daud WAMW, Chakrabarti MH. Renew Sust Energy Rev. 2012;16:5584-5596. DOI: 10.1016/j.rser.2012.06.015.

[17] The Polish Ordinance of Ministry for the Environment from 24 July 2006 about on the conditions which must be fulfilled while discharging waste water to water or ground and on substances particularly dangerous for the water environment (DzU No 137, item 984).

[18] PN-EN 14774-3:2010 - Solid Biofuels - methods for moisture determining using drier method. Part 3 moisture analysis in general sample.

[19] PN-EN 15402:2011 - Solid recovered fuels - Determination of volatile content.

[20] PN-EN 15403:2011 - Solid recovered fuels - Determination of ash content.

[21] Viana H, Vega-Nieva DJ, Oritz Torres L, Lousada J, Aranha J. Fuel. 2012;102:737-745. DOI: 10.1016/j.fuel.2012.06.035.

[23] Vamuuka D, Zografos D, Alevizos G. Biores Technol. 2008;99:3534-3544. DOI: 10.1016/j.biortech.2007.07.049.

[24] CEN/TS 15404:2006 - Solid recovered fuels. Methods for the determination of ash melting behavior by using characteristic temperatures.

[25] Werle S, Wilk RK. Chem Eng Trans. 2012;29:715-720.

\section{WPLYW OCZYSZCZANIA ŚCIEKÓW I SPOSOBU ZAGOSPODAROWANIA OSADÓW ŚCIEKOWYCH NA PROCES ZGAZOWANIA}

\author{
Wydział Inżynierii Środowiska i Energetyki, Politechnika Śląska
}

\begin{abstract}
Abstrakt: Oczyszczanie ścieków prowadzi do powstawania dużej ilości osadów ściekowych, które z punktu widzenia środowiska należy bezpiecznie zagospodarować. Ilość osadów zależy zarówno od zastosowanej metody oczyszczania ścieków, jak i sposobu ich zagospodarowania (tlenowa lub beztlenowa stabilizacja, suszenie itp.). Biorąc to pod uwagę, w pracy badano równocześnie wpływ konfiguracji oczyszczania ścieków oraz metody suszenia osadów na parametry paliwa zastępczego otrzymanego z osadów i skład gazu powstającego podczas ich zgazowania. Zgazowanie bowiem jest obecnie perspektywiczną i alternatywną metodą zagospodarowania osadów ściekowych. Na potrzeby realizacji pracy został zaprojektowany i zbudowany reaktor zgazowania ze złożem stałym. Analizie poddano dwa różne typy osadów ściekowych oznaczone jako SS1 i SS2. Osad ściekowy SS1 pochodził $\mathrm{z}$ oczyszczalni ścieków pracującej $\mathrm{w}$ układzie mechaniczno-biologicznym, a osad SS2 z oczyszczalni mechaniczno-biologiczno-chemicznej z symultanicznym strącaniem fosforu. Powstające w oczyszczalniach osady poddawane są procesowi fermentacji, a następnie po odwodnieniu są suszone w suszarce cylindrycznej na półkach podgrzanych do $260^{\circ} \mathrm{C}$ (osad ściekowy SS1) i przy użyciu gorącego powietrza o temperaturze $150^{\circ} \mathrm{C}$ w suszarce taśmowej (osad SS2). Na podstawie przeprowadzonych badań wykazano, że właściwości osadów ściekowych wyraźnie zależą od rodzaju zastosowanej metody oczyszczania ścieków,
\end{abstract}


jak również sposobu zagospodarowania osadów ściekowych. Rezultaty procesu zgazowania analizowanych osadów prezentowane w funkcji ilości czynnika zgazowującego wskazują, że większa zawartość tlenu w próbce SS1 powoduje obniżenie temperatury reakcji zgazowania. Paradoksalnie, prowadzi to do wzrostu ilości palnych składników w gazie. Z kolei wzrost ilości strumienia czynnika zgazowującego prowadzi do obniżenia wartości opałowej otrzymanego gazu. Wyższa zawartość tlenu rosnąca wraz ze wzrostem ilości czynnika zgazowującego powoduje wzrost niepalnych składników w gazie (głównie azotu).

Słowa kluczowe: oczyszczanie ścieków, obróbka osadów, właściwości osadów, zgazowanie, właściwości paliwowe, parametry gazu ze zgazowania 